\author{
Maciej Kalwasiński \\ Uniwersytet Ekonomiczny we Wrocławiu \\ e-mail: maciej.kalwasinski@ue.wroc.pl
}

\title{
BEZPOŚREDNIE INWESTYCJE ZAGRANICZNE CHIN W POLSCE - PROBLEM RZECZYWISTEJ SKALI INWESTYCJI
}

\section{CHINA'S FOREIGN DIRECT INVESTMENTS IN POLAND - PROBLEM OF AN ACTUAL SCALE OF INVESTMENT}

DOI: 10.15611/pn.2018.523.14

JEL Classification: F21

\begin{abstract}
Streszczenie: Dynamiczny wzrost chińskich bezpośrednich inwestycji zagranicznych w ostatnich latach budzi niepokój rządów i obywateli państw odbiorców kapitału pochodzącego z Chin. Wiele podmiotów udostępnia dane dotyczące dwustronnych przepływów kapitałowych, jednak część źródeł publikuje informacje nierzetelne, niekompletne i zniekształcające obraz chińskiego zaangażowania $\mathrm{w}$ formie BIZ na świecie, w tym w Polsce. W artykule porównano źródła statystyk o wielkości chińskich BIZ w Polsce, wskazując ich wady i zalety oraz formułując rekomendacje dla optymalnego zastosowania.
\end{abstract}

Słowa kluczowe: bezpośrednie inwestycje zagraniczne, BIZ, Chiny.

Summary: The dynamic growth of China's FDI in recent years raises concerns of governments and citizens of the recipient countries. Many entities provide data on bilateral capital flows, however, some sources publish information that is unreliable, incomplete and distorts the picture of an actual Chinese engagement in the form of FDI in the world, especially Poland. In this article the author compares sources of statistics of the Chinese FDI in Poland, indicates their advantages and disadvantages and formulates recommendations for anoptimal use.

Keywords: foreign direct investment, FDI, China.

\section{Wstęp}

Dotychczasowy model rozwoju gospodarczego Chin, oparty na ogromnych nakładach inwestycyjnych, przyciąganiu inwestycji zagranicznych, niskich kosztach pracy i handlu zagranicznym staje się coraz mniej efektywny i powoduje narastanie nierównowag makroekonomicznych w gospodarce. Skłania to chińskie władze 
w Pekinie do reformułowania założeń i celów polityki gospodarczej państwa. Jednym z jej elementów jest zwiększenie aktywności na arenie międzynarodowej. O ile dotychczasowy model rozwoju gospodarczego wymagał przede wszystkim zagwarantowania dostępu do surowców i chińskie bezpośrednie inwestycje zagraniczne (BIZ) były lokowane głównie w tym sektorze, o tyle w nowym modelu, stawiającym mocniej na jakość niż wzrost oraz znaczący awans chińskich firm w globalnym łańcuchu wartości, kluczową kwestią jest uzyskanie dostępu do innego rodzaju aktywów - nowych technologii, know-how, znanych marek. Ponadto znaczny wzrost kosztów pracy w Chinach skłania chińskie przedsiębiorstwa do poszukiwania relatywnie taniej siły roboczej za granica, a spowolnienie tempa wzrostu gospodarki przy równoczesnym przeroście mocy produkcyjnych - możliwości rozwoju na dużych rynkach zagranicznych. Pod rządami przewodniczącego Xi Jinpinga większe są również polityczne ambicje międzynarodowe Chin.

W tym kontekście niefinansowe chińskie przedsiębiorstwa państwowe oraz prywatne coraz częściej podejmują decyzję o różnorodnych formach alokacji kapitału za granicą - głównie BIZ i inwestycjach portfelowych, oraz biorą udział w publicznych przetargach na realizację projektów infrastrukturalnych. Przedsiębiorstwom niefinansowym w procesie internacjonalizacji zazwyczaj asystują chińskie banki zarówno komercyjne, jak i rozwojowe, zapewniając dostęp do kredytu dla chińskich firm lub zagranicznych zleceniodawców.

Globalnej ekspansji Chin z niepokojem przyglądają się rządy i obywatele innych państw, w tym demokratycznych krajów Zachodu. Panuje przekonanie, że do osiągania celów pozaekonomicznych dążą nie tylko podmioty kontrolowane bezpośrednio przez władze, ale również podmioty prywatne, które de facto realizują politykę formułowaną przez Komunistyczną Partię Chin. Obawy szczególnie nasiliły się w ostatnich dwóch latach, co było spowodowane znacznym wzrostem wolumenu chińskich BIZ, głównie w krajach rozwiniętych, w tym w sektorze nowoczesnych technologii, oraz konsolidacją władzy w rękach Xi. Stany Zjednoczone i Unia Europejska już szykują zaostrzenie regulacji umożliwiających ochronę strategicznych sektorów gospodarki przed chińskimi inwestorami. Z drugiej strony chińskie władze coraz częściej kuszą partnerów wizjami atrakcyjnych inwestycji, wbijając klin między kraje zmuszone wybierać pomiędzy realizacją interesów ekonomicznych i politycznych, m.in. w ramach UE.

W tym kontekście dostęp do wiarygodnych danych jest niezbędny dla analizy: faktycznego poziomu alokacji BIZ przez podmioty kontrolowane przez chińskie firmy i determinantów tego typu decyzji, a w konsekwencji formułowania polityki przez kraje goszczące chińskie inwestycje. Zbieraniem i rozpowszechnianiem danych dotyczących BIZ zajmuje się wiele podmiotów (m.in. UNCTAD, Eurostat, OECD, MFW czy ECB), ale nieliczne prowadzą własne wyliczenia dotyczące BIZ dwustronnych - organizacje międzynarodowe, które publikują statystyki dot. BIZ w przekroju sektorowym i geograficznym (UNCTAD, OECD, Eurostat), bazują na danych zebranych przez podmioty kraju macierzystego inwestora i kraju goszczącego. W przypadku chińskich BIZ w Polsce wyżej wymienione organizacje pole- 
gają na wyliczeniach Narodowego Banku Polskiego, a UNCTAD publikuje również dane, opierając się na wyliczeniach chińskich instytucji rządowych.

Obok podmiotów publicznych zbieraniem danych dotyczących chińskich BIZ w przekroju sektorowym i geograficznym zajmują się również podmioty prywatne - firmy doradcze (m.in. PwC), ośrodki analityczne (m.in. Rhodium Group, the Heritage Foundation), podmioty należące do grup medialnych tworzące komercyjne bazy danych (m.in. fDi Markets i Thomson Reuters Datastream). Niektóre ze źródeł udostępniają zebrane dane bezpłatnie, inne - odpłatnie, co ma niebagatelny wpływ na możliwość ich wykorzystania m.in. w badaniach naukowych.

Żadne z wyżej wymienionych źródeł nie zapewnia jednak kompletnych i wiarygodnych danych o napływie chińskich BIZ do poszczególnych krajów świata. Kalkulacje są sprzeczne, wybrakowane czy wręcz nieprawdziwe. Jest to szczególnie problematyczne w przypadku państw niewielkich lub takich, gdzie zaangażowanie przedsiębiorstw z Chin jest mniejsze. Do tych ostatnich należy również Polska. W niniejszym artykule autor porównuje źródła statystyk o wielkości chińskich BIZ w Polsce, wskazuje wady i zalety poszczególnych źródeł oraz formułuje rekomendacje dla optymalnego zastosowania dostępnych danych.

\section{Oficjalne dane chińskie i polskie}

Powszechnie wykorzystywanym źródłem w badaniach naukowych dot. chińskich BIZ w Polsce [Heiduk, McCaleb 2014; Éltető, Szunomár 2016; Chiriu 2014] są dane zbierane i udostępniane przez Ministerstwo Handlu ChRL (Ministry of Commerce of the People's Republic of China, MOFCOM). Od 2005 r. w III kwartale każdego roku MOFCOM publikuje, wraz z Narodowym Biurem Statystycznym (National Bureau of Statistics of China, NBS) oraz agencją wchodzącą w skład Ludowego Banku Chin zajmującą się regulowaniem rynku walutowego i zarządzaniem aktywami rezerwowymi ChRL (State Administration of Foreign Exchange, SAFE), „Biuletyn Statystyczny Chińskich Bezpośrednich Inwestycji Zagranicznych” (,Statistical Bulletin of China's Outward Foreign Direct Investment”, w dalszej części artykułu: „Biuletyn”). Dostęp do „Biuletynu” jest bezpłatny, ale utrudniony - dokument jest publikowany na chińskojęzycznej stronie Ministerstwa Handlu ${ }^{1}$ Edycje z lat 2005-2015 są dostępne w języku chińskim i języku angielskim. Ostatnia dostępna obecnie - to znaczy z 2016 r. - została już opublikowana wyłącznie w języku chińskim. Jednak zagregowane dane są także udostępniane w innych źródłach, w tym anglojęzycznych, np. bazie CEIC China Premium Database.

W raporcie z 2008 r. OECD zwraca uwagę, iż „obiektywna deklaracja, że chińskie statystyki BIZ są zgodne z metodologią rekomendowaną w »OECD Benchmark Definition of FDI« (w pełni zgodną z rekomendacjami MFW) jest niemożliwa". Przedstawiciele organizacji wytknęli Chińczykom m.in. brak informacji metodologicznej skutkujący brakiem przejrzystości statystyk. Część postulatów OECD -

\footnotetext{
1 http://fec.mofcom.gov.cn/article/tjsj/.
} 
zebranie danych o łącznej wartości chińskich BIZ na świecie oraz dochodach z BIZ - została do dziś zrealizowana. Wciąż nie wprowadzono za to podziału na główne komponenty BIZ - napływów w formie akcji i innych udziałów kapitałowych, reinwestycji zysków oraz instrumentów dłużnych - w podziale na kraje goszczące i rodzaje działalności gospodarczej podmiotów bezpośredniego inwestowania. Nie uporano się również z problemem „round-trippingu”, o którym mowa będzie w dalszej części artykułu. Aneks metodologiczny, którego brak wytykała OECD, we wszystkich edycjach „Biuletynu” jest dostępny jedynie w języku chińskim.

Chiny zachowują jednak podstawowe standardy międzynarodowe określone w dokumencie „OECD Benchmark Definition of FDI” - pod pojęciem BIZ rozumieją objęcie co najmniej $10 \%$ głosów w zagranicznym przedsiębiorstwie przez inwestora krajowego, zarówno w formie inwestycji typu greenfield, jak i fuzji i przejęć [MOFCOM 2015]. Według wyliczeń MOFCOM, NBS i SAFE (dalej: MOFCOM) na koniec 2016 r. skumulowana wartość chińskich BIZ za granicą wyniosła 1,36 bln dolarów w porównaniu z 29,9 mld dolarów na koniec 2002 r., co dało Chinom awans z 25. na 6. miejsce na świecie. W 2015 r. kraj stał się eksporterem kapitału netto w formie BIZ - wartość odpływu przekroczyła wartość napływu. W 2016 r. wartość chińskich BIZ na świecie osiągnęła rekordowy poziom 196,2 mld dolarów.

Mimo że w „Biuletynie” zawarto informacje na temat struktury geograficznej BIZ, to nie mogą one służyć rzetelnej analizie kierunków zaangażowania przedsiębiorstw z Państwa Środka. Według tych danych w 2016 r. ponad 71\% chińskich BIZ zostało ulokowanych $\mathrm{w}$ trzech centrach finansowych offshore ${ }^{2}-$ Hongkongu, na Wyspach Dziewiczych i Kajmanach. W ostatnich 10 latach trafiło tam blisko $69 \%$ chińskich BIZ. Głównym odbiorcą inwestycji jest Hongkong, gdzie w ostatnim dziesięcioleciu rocznie lokowano od 47,76\% do nawet $69,12 \%$ wszystkich BIZ.

Tabela 1. Udział głównych centrów finansowych offshore w chińskich BIZ w latach 2007-2016 według MOFCOM (w \%)

\begin{tabular}{|l|r|r|r|r|r|r|r|r|r|r|}
\hline & \multicolumn{1}{|c|}{2007} & 2008 & \multicolumn{1}{|c|}{2009} & 2010 & \multicolumn{1}{|c|}{2011} & 2012 & 2013 & 2014 & 2015 & \multicolumn{1}{c|}{2016} \\
\hline Hongkong & 51,81 & 69,12 & 62,98 & 55,96 & 47,76 & 58,36 & 58,25 & 57,56 & 61,64 & 58,24 \\
\hline Wyspy Dziewicze & 7,08 & 3,76 & 2,85 & 8,89 & 8,32 & 2,55 & 2,99 & 3,71 & 1,27 & 6,26 \\
\hline Kajmany & 9,82 & 2,73 & 9,49 & 5,08 & 6,61 & 0,94 & 8,58 & 3,40 & 7,01 & 6,89 \\
\hline Łącznie & 68,70 & 75,61 & 75,32 & 69,93 & 62,69 & 61,85 & 69,82 & 64,68 & 69,92 & 71,40 \\
\hline Pozostałe & 31,30 & 24,39 & 24,68 & 30,07 & 37,31 & 38,15 & 30,18 & 35,32 & 30,08 & 28,60 \\
\hline
\end{tabular}

Źródło: opracowanie własne na podstawie oficjalnych chińskich danych [MOFCOM, 2015 oraz 2016].

Chińskie firmy tworzą spółki offshore w odpowiedzi na niedoskonałości rynku wewnętrznego, które powstały i są podtrzymywane przez działania władz - ograniczony dostęp do finansowania, słabą ochronę praw własności, ograniczanie niektó-

${ }^{2}$ MFW definiuje centrum finansowe offshore jako „kraj lub terytorium, które dostarcza usługi finansowe nierezydentom w skali niewspółmiernej do wielkości i finansowania gospodarki wewnętrznej" [Zorome 2007]. 
rych BIZ czy relatywnie wysokie obciążenia podatkowe. Dlatego wiele chińskich firm inwestuje za granicą i w kraju poprzez finansowe centra offshore, które oferują profesjonalne usługi, bezpieczniejsze otoczenie instytucjonalne oraz umożliwiają przedsiębiorcom z Państwa Środka ukrycie narodowości, co ułatwia realizację projektów w przypadku odbiorców BIZ sceptycznie nastawionych do chińskich inwestorów lub możliwość zablokowania danej inwestycji zagranicznej przez władze ChRL, a także reinwestycję w Chinach jako inwestor zagraniczny (tzw. round-tripping) korzystający z zachęt podatkowych [Buckley i in. 2013].

Łączny udział Hongkongu, Wysp Dziewiczych i Kajmanów w całkowitym stanie należności z tytułu chińskich BIZ na świecie utrzymuje się na poziomie ok. 70\%, a w ostatnich dwóch latach nawet nieznacznie wzrósł - z 68,4\% w 2014 r. do 71,8\% w 2016 r. To wyraźnie wyższy odsetek niż w przypadku wszystkich światowych BIZ - szacuje się, że przynajmniej 30\% przechodzi przez finansowe centra offshore [Haberly, Wójcik 2014]

Tabela 2. Udział głównych centrów finansowych offshore w stanie należności z tytułu chińskich BIZ na koniec lat 2012-2016 według MOFCOM (w \%)

\begin{tabular}{|l|r|r|r|r|r|}
\hline & 2012 & 2013 & 2014 & 2015 & 2016 \\
\hline Hongkong & 57,6 & 58,3 & 57,8 & 59,8 & 57,5 \\
\hline Wyspy Dziewicze & 5,6 & 8,6 & 5,6 & 5,7 & 7,7 \\
\hline Kajmany & 5,8 & 3 & 5 & 4,7 & 6,6 \\
\hline Łącznie & 69,0 & 69,9 & 68,4 & 70,2 & 71,8 \\
\hline
\end{tabular}

Źródło: opracowanie własne na podstawie oficjalnych chińskich danych [MOFCOM, edycje 2012-2016].

Praktyka biznesowa chińskich przedsiębiorstw wraz z regulacjami zobowiązującymi ich do raportowania jurysdykcji, w których BIZ są lokowane jako pierwsze, a nie te, które są docelowym miejscem inwestycji, sprawia, że struktura geograficzna BIZ przedstawiona w oficjalnych danych nie odpowiada rzeczywistej. Dokładny pomiar BIZ utrudnia także zmieniające się otoczenie regulacyjne - władze przez lata stopniowo ograniczały zakres inwestycji zagranicznych wymagających zgody i rejestracji, ale w celu zahamowania przyspieszonego odpływu kapitału z Chin, w 2017 r. ponownie zaostrzyły ograniczenia [Goh, Glenn, McClellan 2017]. Teraz zostały one częściowo rozluźnione [Shepherd, Mason, Coghill 2017]. W okresie mniej restrykcyjnych regulacji mniejsze inwestycje są pomijane, a w okresie większych restrykcji inwestycje o tej samej skali są już odnotowywane.

Po stronie polskiej za publikację danych o BIZ odpowiada Narodowy Bank Polski (NBP). Polski bank centralny dochowuje międzynarodowych standardów, stosując wytyczne z czwartej edycji „OECD Benchmark Definition of FDI”, które są w pełni spójne z koncepcjami i definicjami z szóstej edycji standardu MFW, dotyczącego bilansu płatniczego i międzynarodowej pozycji inwestycyjnej. NBP zaznacza, że „standard statystyki inwestycji bezpośrednich dopuszcza różne metody zbie- 
rania danych i wyceny aktywów. Między danymi występują zatem różnice będące wynikiem zastosowania odmiennych metod" [NBP 2018].

W dokumentach NBP używane jest pojęcie zagranicznych inwestycji bezpośrednich, definiowane jako ,inwestycje inwestorów bezpośrednich będących nierezydentami w podmioty bezpośredniego inwestowania - rezydentów. Dotyczy to sytuacji, kiedy nierezydenci (inwestorzy bezpośredni) wywierają wpływ na rezydentów (podmioty bezpośredniego inwestowania) lub kontrolują ich. Wywieranie wpływu należy rozumieć jako dysponowanie bezpośrednio i/lub pośrednio co najmniej $10 \%$ głosów w organie stanowiącym innego podmiotu, a sprawowanie kontroli jako dysponowanie bezpośrednio i/lub pośrednio więcej niż $50 \%$ głosów w organie stanowiącym innego podmiotu" [NBP 2018].

Źródłem danych o BIZ w Polsce są przesyłane do NBP sprawozdania od rezydentów, których suma aktywów przekracza $7 \mathrm{mln}$ zł (w przypadku osób fizycznych) lub $10 \mathrm{mln}$ zł (pozostali rezydenci, inni niż firmy inwestycyjne). Firmy inwestycyjne (w tym banki) składają sprawozdania niezależnie od wielkości posiadanych aktywów i pasywów zagranicznych. Źródłem danych o BIZ w Polsce, opartych na papierach wartościowych, są sprawozdania przesyłane przez emitentów lub pośredników finansowych. Dane o spółkach mających zdematerializowane akcje są zbierane na podstawie dostępnych sprawozdań finansowych emitentów oraz miesięcznych sprawozdań banków powierniczych i domów maklerskich. Bank zaznacza również, że „dodatkowymi źródłami informacji są informacje prasowe, sprawozdania finansowe podmiotów oraz bezpośrednie kontakty z podmiotami" [NBP 2018].

Polski bank centralny raportuje o wielkości napływów BIZ do Polski, stanie zobowiązań Polski z tytułu BIZ oraz dochodach zagranicznych inwestorów z tytułu zainwestowanego w Polsce kapitału w postaci BIZ. We wszystkich kategoriach NBP dostarcza informacji w podziale na kraje i strefy ekonomiczne oraz w podziale na rodzaje działalności gospodarczej podmiotów bezpośredniego inwestowania. Ponadto wszystkie kategorie składają się z bardziej szczegółowych komponentów (w przeciwieństwie do oficjalnych chińskich danych). W skład napływu kapitału z tytułu BIZ do Polski wchodzą akcje i inne formy udziałów kapitałowych, reinwestowane zyski oraz zmiany należności i zobowiązań, które mają związek z zadłużeniem pomiędzy podmiotami powiązanymi kapitałowo. W stanie zobowiązań z tytułu BIZ znajdują się powyższe komponenty, oprócz reinwestowanych zysków, a w dochodach - dywidendy, reinwestowane zyski oraz dochody od wierzytelności. Dekompozycja szerszych agregatów umożliwia bardziej dokładną analizę BIZ w Polsce.

Dane publikowane przez NBP wyraźnie różnią się od przedstawionych w kolejnych edycjach „Biuletynu”. Różnice sięgają od 5 do $220 \mathrm{mln}$ USD rocznie. Strona polska czterokrotnie zaraportowała wyższy napływ niż chińska odpływ, a sześciokrotnie było na odwrót. Polski bank centralny zdecydowanie częściej wykazywał dezinwestycje (5 razy w ostatnich 10 latach i 4 razy w ostatnich 5 latach wobec jednego takiego odczytu strony chińskiej). 
Tabela 3. BIZ napływające do Polski z Chin w latach 2007-16 według NBP i MOFCOM [mln USD]

\begin{tabular}{|l|c|r|r|r|r|r|r|r|r|c|}
\hline & \multicolumn{1}{|c|}{2007} & \multicolumn{1}{c}{2008} & \multicolumn{1}{c}{2009} & \multicolumn{1}{c}{2010} & \multicolumn{1}{c}{2011} & \multicolumn{1}{c}{2012} & \multicolumn{1}{c}{2013} & 2014 & 2015 & \multicolumn{1}{c}{2016} \\
\hline NBP & 95,88 & 130,41 & -209 & 0 & 101,22 & $-148,47$ & $-29,4$ & 83,9 & $-2,2$ & $-29,2$ \\
\hline MOFCOM & 11,75 & 10,7 & 10,37 & 16,74 & 48,66 & 7,5 & 18,34 & 44,17 & 25,1 & $-24,11$ \\
\hline P-Ch & 84,13 & 119,71 & $-219,37$ & $-16,74$ & 52,56 & $-155,97$ & $-47,74$ & 39,73 & $-27,3$ & $-5,09$ \\
\hline
\end{tabular}

Źródło: opracowanie własne na podstawie danych zebranych w bazie UNCTAD Bilateral FDI Statistics dla lat 2007-12 oraz raportów NBP „Zagraniczne inwestycje bezpośrednie w Polsce i polskie inwestycje bezpośrednie za granicą” (NBP) i „Biuletynów” (MOFCOM) za lata 2013-2016.

Chińczycy nie raportują o komponentach BIZ w krajach-odbiorcach chińskich inwestycji. Dlatego nie ma możliwości porównania, w którym elemencie odczyty różnią się, wpływając na powstanie rozbieżności w danych o BIZ. Z danych polskiego banku centralnego wynika, że za ujemne napływy BIZ z Chin w ostatnich 5 latach odpowiadały głównie: ujemne zmiany należności i zobowiązań, np. w wyniku spłaty zobowiązań spółek-córek wobec spółek-matek $(2012,2013)$ oraz ujemne reinwestowane zyski, np. wypłata zysków z lat ubiegłych $(2015,2016)$.

Różnica kilkudziesięciu czy nawet kilkuset milionów dolarów rocznie w wypadku największych odbiorców chińskich BIZ nie wpływała znacząco na analizę zaangażowania inwestorów z Państwa Środka w danym roku, jednak w przypadku takiego odbiorcy jak Polska jest kluczowa, gdyż łączna wartość chińskich BIZ w Polsce sięga według NBP zaledwie kilkuset milionów dolarów. Na koniec 2016 r. raportowany przez NBP stan należności wobec Chin stanowił zaledwie ok. 40\% podawanego przez stronę chińską, tymczasem jeszcze w 2011 r. sytuacja była przeciwna - stan raportowany przez Chińczyków sięgał niespełna 50\% raportowanego przez stronę polską.

Tabela 4. Stan zobowiązań Polski wobec Chin z tytułu BIZ w latach 2007-16 według NBP i MOFCOM [mln USD]

\begin{tabular}{|l|r|c|c|c|c|r|r|r|r|r|}
\hline & \multicolumn{1}{|c|}{2007} & 2008 & \multicolumn{1}{c}{2009} & 2010 & 2011 & 2012 & \multicolumn{1}{|c|}{2013} & \multicolumn{1}{c}{2014} & \multicolumn{1}{c}{2015} & \multicolumn{1}{c|}{2016} \\
\hline NBP & 203,61 & 336,15 & 188,47 & 303,73 & 413,7 & 288,1 & 104,2 & 179,1 & 217,94 & 130,5 \\
\hline MOFCOM & 98,93 & 109,93 & 120,3 & 140,31 & 201,26 & 208,11 & 257,04 & 329,35 & 352,11 & 321,32 \\
\hline P-Ch & 104,68 & 226,22 & 68,17 & 163,42 & 212,44 & 79,99 & $-152,84$ & $-150,23$ & $-134,17$ & $-190,82$ \\
\hline
\end{tabular}

Źródło: opracowanie własne na podstawie danych zebranych w bazie UNCTAD Bilateral FDI Statistics dla lat 2007-2012 oraz raportów NBP „Zagraniczne inwestycje bezpośrednie w Polsce i polskie inwestycje bezpośrednie za granicą” (NBP) i „Biuletynów” (MOFCOM) za lata 2013-2016.

Na podstawie powyższych danych o przepływach dwustronnych oraz geograficznej strukturze chińskich BIZ można domniemywać, że MOFCOM dostrzega głównie pierwszy odpływ kapitału z Chin, natomiast kolejne przepływy umykają jego uwadze (choć reinwestowane zyski są przez niego zaliczane do BIZ zgodnie z międzynarodowymi standardami i prezentowane przy okazji łączne wartości 
chińskich BIZ na świecie). Różnice między odczytami mogą wynikać również $\mathrm{z}$ innego momentu odnotowania inwestycji czy też, także z tym związanych, kursów walutowych przyjętych do przeliczeń.

Gdyby do danych NBP o BIZ napływających do Polski z Chin doliczyć BIZ z Hongkongu ${ }^{3}$, to różnice pogłębiają się - w przypadku napływów rocznych wynoszą od $22 \mathrm{mln}$ dol. do 412 mln dol., w przypadku stanów należności z 40\% do 19\%.

Tabela 5. Napływ kapitału z tytułu BIZ do Polski z Hongkongu i stan należności Polski z tytułu BIZ wobec Hongkongu w latach 2007-2016 według NBP [mln dol.]

\begin{tabular}{|l|c|c|c|c|r|r|r|r|r|c|}
\hline & 2007 & 2008 & 2009 & \multicolumn{1}{c}{2010} & \multicolumn{1}{c}{2011} & \multicolumn{1}{c}{2012} & \multicolumn{1}{c}{2013} & 2014 & 2015 & 2016 \\
\hline Napływ & 31,25 & $-27,60$ & 192,43 & $-81,92$ & $-230,76$ & 113,22 & 70,3 & 17,7 & 159,1 & $-63,9$ \\
\hline Stan & 60,78 & $-6,82$ & 185,77 & 386,59 & 150,73 & 268,42 & 261,1 & 288,7 & 421,0 & 351,6 \\
\hline
\end{tabular}

Źródło: opracowanie własne na podstawie danych NBP.

Na danych zebranych przed podmioty krajowe bazują m.in. OECD, UNCTAD i Eurostat, które również udostępniają statystyki dot. dwustronnych BIZ. Baza UNCTAD Bilateral FDI Statistics gromadzi odczyty do 2012 r. i umożliwia dostęp do statystyk według kraju zgłaszającego - są one takie same jak raportowane przez odpowiednio NBP i MOFCOM, a w niektórych przypadkach różnią się bardzo nieznacznie, co wynika z uaktualnień dokonanych przez podmioty krajowe. Bazy OECD i Eurostatu funkcjonują na tej samej zasadzie, z tym że dostępne są wyłącznie wyliczenia raportowane przez NBP.

Polski bank centralny, w myśl najnowszych zaleceń organizacji międzynarodowych, stara się również klasyfikować inwestorów według kraju, w którym siedzibę ma podmiot dominujący w grupie kapitałowej (ultimate investor). Po wyeliminowaniu z wyliczeń spółek rejestrowanych w Niderlandach i Luksemburgu ${ }^{4}$, zakładanych przez spółki z innych krajów ,jako pośrednie ogniwo w łańcuchu własności w grupach kapitałowych w celu swobodniejszego dysponowania docelową inwestycją i korzystniejszego opodatkowania dochodów pasywnych" [NBP 2018], istotnie zmienia się obraz geograficznej struktury BIZ w Polsce, w tym szacowany poziom stanu zobowiązań wobec Chin.

Tabela 6. Stan zobowiązań z tytułu BIZ w Polsce według kraju siedziby podmiotu dominującego na koniec roku według NBP [mln dol.]

\begin{tabular}{|l|c|c|c|c|}
\hline & 2013 & 2014 & 2015 & 2016 \\
\hline Chiny & 641 & 502 & 928 & 588 \\
\hline Hongkong & 238 & 296 & 518 & 287 \\
\hline
\end{tabular}

Źródło: opracowanie własne na podstawie danych NBP publikowanych przez OECD.

3 Specjalny Region Administracyjny ChRL.

${ }^{4}$ Według MOFCOM Niderlandy są 7. największym odbiorcą chińskich BIZ z udziałem 1,5\%, a Luksemburg - 12. z udziałem $0,6 \%$ na koniec 2016 r. 
Porównanie danych z tab. 4-6 wskazuje, że podmioty z Chin inwestują w Polsce za pośrednictwem podmiotów ulokowanych w innych krajach, a faktyczny poziom ich zaangażowania w Polsce jest znacznie wyższy, niż dotychczas sądzono, polegając na danych NBP z corocznego raportu ,Zagraniczne inwestycje bezpośrednie w Polsce". Przy relatywnie niewielkim stanie zobowiązań wobec Chin z tytułu BIZ według kraju inwestora bezpośredniego (IIC - Immediate Investor Country) kwalifikacja według kraju podmiotu kontrolującego inwestora bezpośredniego (UIC Ultimate Investor Country) wskazuje kilkukrotnie wyższy faktyczny poziom zaangażowania kapitału zarządzanego ostatecznie przez podmioty z Chin.

Tabela 7. Stan zobowiązań z tytułu BIZ w Polsce wobec Chin w latach 2013-16 [mln dol.]

\begin{tabular}{|l|r|r|r|r|}
\hline & 2013 & 2014 & 2015 & \multicolumn{1}{c|}{2016} \\
\hline NBP wg IIC & 104,2 & 179,1 & 217,94 & 130,5 \\
\hline NBP wg UIC & 641 & 502 & 928 & 588 \\
\hline
\end{tabular}

Źródło: opracowanie własne na podstawie danych NBP.

Polski bank centralny podkreśla ponadto, że często zidentyfikowanie kraju siedziby podmiotu dominującego w grupie kapitałowej, do której należy inwestor bezpośredni, jest problematyczne (fundusze private equity), a w przypadku osób fizycznych nawet niemożliwe. Podmioty te korzystają z regulacji prawnych obowiązujących w centrach finansowych offshore i zachowują anonimowość. W efekcie udział inwestorów bezpośrednich, dla których kraj będący siedzibą podmiotu dominującego w grupie kapitałowej był niesklasyfikowany, wyniósł 11,6\% zobowiązań z tytułu BIZ na koniec 2016 r. [NBP 2018].

Na szerszy problem z pomiarem BIZ zwrócili uwagę O. Blanchard i J. Acalin. BIZ powstają ich zdaniem w wyniku decyzji opartych na czynnikach długoterminowych, tymczasem zauważyli wysoką korelację między wartością napływów i odpływów BIZ w latach 1990-2015 w kilku krajach rozwijających się, w tym w Polsce, oraz między wartością napływów i odpływów BIZ w tych państwach a polityką monetarną amerykańskiej Rezerwy Federalnej. „Sugeruje to, że zmierzone BIZ różnią się od prawdziwych BIZ i mogą raczej odzwierciedlać przepływy przez kraj, a nie do niego, z przystankiem na legalną optymalizację podatkową" - konkludują [Blanchard, Acalin 2016].

Przed kilkunastoma laty informacje na temat wartości chińskich BIZ w Polsce publikował jeszcze jeden podmiot publiczny - Polska Agencja Informacji i Inwestycji Zagranicznych [PAIiIZ 2004]. Obecnie Polska Agencja Inwestycji i Handlu (PAIH, zmiana nazwy nastąpiła w 2017 r.) informuje o liczbie szykowanych we współpracy z Agencją BIZ i ich deklarowanej przez inwestorów wartości, wraz z planowaną liczbą utworzonych miejsc pracy. W styczniu 2018 r. PAIH miała w swoim portfelu 11 chińskich inwestycji o łącznej wartości 1,27 mld euro [Kalwasiński 2018]. Dane te można traktować pomocniczo - jako wcześniejszą zapowiedź potencjalnych inwestycji i poziom wstępnego zainteresowania inwestorów ulokowaniem kapitału w Polsce. 


\section{Dane publikowane przez podmioty prywatne}

Cząstkowe informacje na temat chińskich BIZ w Polsce publikują również podmioty prywatne. Źródła te można podzielić na bezpłatne i odpłatne oraz agregujące wszystkie zidentyfikowane BIZ i wyłącznie jeden typ - greenfield albo fuzje i przejęcia. Ich podstawową zaletą jest to, że identyfikują podmiot kontrolujący inwestora bezpośredniego i są publikowane znacznie szybciej niż dane oficjalne. Natomiast wspólną wadą, istotną szczególnie w przypadku BIZ w Polsce, jest fakt, że pomijają mniejsze inwestycje.

Bezpłatnie szczegółowe dane źródłowe dotyczące chińskich BIZ na świecie, w tym w Polsce, udostępnia The Heritage Foundation wraz z The American Enterprise Institute, a Rhodium Group we współpracy z Mercator Institute for Chinese Studies publikuje raporty, w których podaje skumulowaną sumę napływów w danym roku.

The Heritage Foundation wraz z The American Enterprise Institute stworzył The China Global Investment Tracker (CGIT). Jak wskazują autorzy, jest to ,jedyny kompleksowy zestaw danych obejmujących inwestycje w działalność budowlaną Chin na świecie”. Dane obejmują okres od 2005 r. i są uaktualniane co pół roku. Obecnie zbiór transakcji w kategorii inwestycje liczy ponad 1300 rekordów. Minimalna wartość transakcji to $100 \mathrm{mln}$ dol. Specyfika bazy sprawia, że jest ona prawie nieprzydatna do analizy chińskich BIZ w Polsce, ponieważ uwzględnia jedynie relatywnie duże inwestycje, a ponadto uwzględnia transakcje ogłoszone w mediach, a nie faktycznie zrealizowane. CGIT w kategorii inwestycje zawiera jedynie cztery rekordy dotyczące Polski w ciągu 13 lat, z tego jeden - akwizycja Konsalnetu za 110 mln USD w 2017 r. - została co prawda ogłoszona, ale inwestor szybko się wycofał i transakcje nie została zrealizowana [Kalwasiński 2018]. Podobnych transakcji jest więcej, choć nie w przypadku Polski - CGIT podaje np., że CEFC zainwestował ponad miliard euro w zwiększenie udziałów w J\&T Finance z 9,9\% do 50\%. Inwestycje zablokował Czeski Bank Narodowy, a CEFC wstrzymał się od odwołania [Kynge 2018]. W zbiorze widnieją również transakcje niespełniające definicji BIZ, np. objęcie 5\% udziałów.

Od 2015 r. Rhodium Group we współpracy z Mercator Institute for Chinese Studies wydaje opracowania dotyczące chińskich BIZ w Unii Europejskiej. Autorzy nie publikują zestawu danych źródłowych, lecz podają łączną wartość skumulowanych od 2000 r. napływów do poszczególnych krajów. Zbiór danych jest opracowywany przez analityków Rhodium Group, którzy ,śledzą inwestycje firm z Chin kontynentalnych w UE, używając różnorodnych kanałów, tj. komercyjne bazy danych, internetowe algorytmy szukające, doniesienia medialne, oficjalne sprawozdania i raporty spółek, stowarzyszeń branżowych, źródeł sądowych, agencji promujących inwestycje, kontaktów branżowych oraz innych źródeł. Zbiór danych obejmuje tylko te transakcje, które kwalifikują się jako bezpośrednie inwestycje zagraniczne zgodnie ze standardami międzynarodowymi, tzn. inwestycje typu greenfield oraz 
objęcia przynajmniej 10\% udziałów lub głosów w istniejących spółkach (...) Minimalna wartość transakcji uwzględnianych w danych to milion euro" [Hanemann, Huotari 2015]. Przejęcia są włączane do statystyk w momencie zakończenia procesu akwizycji, a ich wartość jest równa oficjalnie ogłoszonej (jeśli raportowana w walucie innej niż euro jest przeliczana po średnim kursie z danego roku) lub szacowana na podstawie liczby pracowników, przychodów czy wyceny podobnych inwestycji. BIZ typu greenfield muszą się rozpocząć, by zostać uwzględnione w zbiorze, i są odnotowywane w momencie startu inwestycji. Wieloletnie projekty są rejestrowane stopniowo, w miarę upływu czasu inwestycji. Autorzy zbioru zwracają jednak uwagę, że dane nie są bezpośrednio porównywalne do danych kompilowanych na podstawie bilansu płatniczego, nie uwzględniają np. przepływów między podmiotami z tej samej grupy kapitałowej, czyli nie wskazują dezinwestycji, gdy mają one miejsce. Różnice mogą również wynikać z odmiennej klasyfikacji transakcji znajdujących się ,na granicy inwestycji portfelowych i bezpośrednich, tj. transakcje na rynku nieruchomości komercyjnych, udziały bez prawa głosu w przemyśle wydobywczym oraz wydatki związane z długoterminowymi umowami najmu, transportem lotniczym i projektami infrastrukturalnymi” [Hanemann, Huotari 2015].

Rhodium Group nie publikuje listy wszystkich transakcji w danym okresie ani wartości napływów w danym roku (z wyjątkiem największych odbiorców BIZ), ale udostępnia je na wniosek przy okazji dorocznego wydania swojego raportu. W latach 2000-2017 skumulowana wartość napływów chińskich BIZ do Polski przekroczyła miliard dolarów, z czego za ponad połowę odpowiada rekordowy 2016 r., w którym odnotowano dwie akwizycje i jedną inwestycję typu greenfield. Spółka-córka China Three Gorges przejęła od portugalskiego EDP Renováveis aktywa w Polsce za $398 \mathrm{mln}$ dol., China Everbright International nabyła większościowy pakiet Novago za 123 mln dol., a Suzhou Chunxing wybudował zakład w Gdańsku za $42 \mathrm{mln}$ dol. W kolejnym roku analitycy Rhodium Group również zidentyfikowali trzy BIZ: grupa Smithfield Foods, należąca do chińskiego potentata WH Group, przejęła zakłady mięsne Pini Polska i Hamburger Pini oraz spółkę Royal Chicken, Jiangsu Olive Sensors High-Tech nabył udziały w polskim oddziale firmy Schürholz, a LiuGong przeniósł europejską siedzibę z Amsterdamu do Warszawy oraz otworzył nową linię produkcyjną maszyn budowlanych i centrum dystrybucji części zamiennych w swoim zakładzie w Stalowej Woli. We wszystkich przypadkach wielkość inwestycji nie została podana do publicznej wiadomości, a ich wartość oszacowano na $100 \mathrm{mln}$ dol. łącznie [Kalwasiński 2018]. Warto również podkreślić, że skumulowana wartość BIZ w danym okresie nie jest tym samym, co stan należności z tytułu BIZ na koniec tego okresu raportowany przez instytucje publiczne zgodnie z międzynarodowymi standardami.

Zestawienie danych tab. 8 z CGIT i Rhodium Group ilustruje wady prywatnych źródeł informacji na temat chińskich BIZ w Polsce. CGIT przyporządkował akwizycję dokonaną przez spółkę-córkę China Three Gorges do 2015 r. (Rhodium Group - do 2016 r.) i oszacował jej wartość na $340 \mathrm{mln}$ dol. (Rhodium Group - 
$398 \mathrm{mln}$ dol.). W przypadku przejęcia Novago (w obu przypadkach odnotowanego w 2016 r.) źródła również różnią się wyceną - Rhodium Group szacuje wartość akwizycji na $123 \mathrm{mln}$ dol., a CGIT na $140 \mathrm{mln}$ dol. Różne wyceny są prawdopodobnie efektem przyjęcia innego kursu walutowego euro/dol. Ani jedno, ani drugie źródło nie wychwyciło zmian w akcjonariacie Biotonu, w którym dwóch chińskich inwestorów objęło w 2016 r. 18- i 10-procentowe udziały, o łącznej wartości w dniu operacji odpowiednio ok. $130 \mathrm{mln}$ zł (ok. $32 \mathrm{mln}$ dol.) i $74 \mathrm{mln}$ zł (ok. $18 \mathrm{mln}$ dol.). Natomiast w 2017 r. CGIT błędnie uwzględnił akwizycje Konsalnetu w swoim zbiorze danych.

Tabela 8. Wartość chińskich BIZ w Polsce w latach 2013-2017 według ośrodków analitycznych (mln USD)

\begin{tabular}{|l|c|c|c|c|c|}
\hline & 2013 & 2014 & 2015 & 2016 & 2017 \\
\hline CGIT & $>100$ & $>100$ & 340 & 140 & 110 \\
\hline Rhodium Group & $>100$ & $>100$ & $>100$ & 563 & 100 \\
\hline
\end{tabular}

Źródło: opracowanie własne na podstawie danych z CGIT i Rhodium Group.

Wśród odpłatnych zbiorów danych dot. chińskich inwestycji na świecie, w tym w Polsce, dominuje podział na zbiory obejmujące wyłącznie BIZ typu greenfield albo fuzje i przejęcia (M\&A). Baza fDi Markets należąca do „Financial Times” to „najobszerniejsza internetowa baza danych dotyczących zagranicznych inwestycji typu greenfield, obejmująca wszystkie kraje i sektory na całym świecie". Zapewnia dostęp do informacji o prowadzonych inwestycjach - nakładach inwestycyjnych i tworzonych miejscach pracy. Dane bazują jednak na zapowiedziach z momentu ogłoszenia inwestycji i mogą się różnić od faktycznych napływów kapitału oraz mogą pomijać mniejsze inwestycje, szczególnie w krajach rozwijających się. Ponadto twórcy bazy sugerują odbiorcom, że to wyłącznie inwestycje typu greenfield są bezpośrednimi inwestycjami zagranicznymi, co jest niezgodne ze standardami międzynarodowymi i może prowadzić do błędnych wniosków ${ }^{5}$. Dostęp do bazy to dla uczelni koszt minimum 7500 funtów rocznie. Z fDi Markets korzystają m.in. agendy ONZ - UNCTAD, raportując o rocznych wartościach inwestycji typu greenfield w poszczególnych krajach w Aneksie do „World Investment Report”, czy $\mathrm{FAO}$, raportująca o BIZ w sektorze rolniczym.

Liczne podmioty prywatne zajmują się zbieraniem danych dotyczących chińskich przejęć i akwizycji. Są to m.in. Thomson Reuters Datastream, ChinaVenture, Zephyr czy Dealogic. Inne podmioty korzystają z zebranych w tych bazach danych i publikują na ich podstawie raporty dotyczące chińskich BIZ na całym świecie lub w poszczególnych regionach czy krajach - obok wspomnianego wyżej Rhodium Group są to przedsiębiorstwa świadczące usługi doradcze w procesie M\&A (np. PwC czy Boston Consulting Group) oraz media („Financial Times” czy agencja

5 Np. sformułowania tezy, że Polska jest drugim największym odbiorcą BIZ w UE [PAIH 2018]. 
Reutera). Dostęp do zbiorów danych jest jednak odpłatny, a podmioty publikujące raporty dotyczące chińskich M\&A analizują kierunki i sektory, którymi chińscy inwestorzy są zainteresowaniu w największym stopniu.

Oddzielna analiza BIZ typu greenfield oraz M\&A jest w niektórych przypadkach uzasadniona. $Z$ dotychczasowych badań wynika, że chińskie przedsiębiorstwa decydujące się na budowę fabryki za granicą kierują się m.in. dostępnością taniej i/lub dobrze wykształconej siły roboczej (efficiency-seeking motive), a w przypadku fuzji i przejęć m.in. pozyskaniem pożądanych aktywów (strategic assets-seeking motive) [Szunomár, Biedermann 2014]. Natomiast proste zsumowanie napływów z tytuły inwestycji typu greenfield i M\&A w danym okresie nie daje całkowitej wartości BIZ w tym okresie, ponieważ żaden ze zbiorów nie musi uwzględniać wszystkich przepływów kapitałowych między podmiotami należącymi do jednej grupy kapitałowej a ulokowanymi w różnych krajach, które w myśl standardów międzynarodowych winny być zaliczane do BIZ. W ten sposób - poprzez dodanie kwot raportowanych przez fDi Markets i Thomson Reuters - powstały wyliczenia opublikowane w ChinaObs fdiMonitor (COFM) przez firmę TAC. Użytkownik nie ma dostępu do szczegółowych informacji o BIZ (np. nazwy inwestora) i nie może potwierdzić ich prawdziwości - widzi liczbę BIZ w danym roku i ich wartość w podziale na sektory.

Tabela 9. Wartość chińskich BIZ w Polsce w latach 2005-2014 według COFM (mln dol.)

\begin{tabular}{|r|c|r|r|r|r|r|r|r|c|}
\hline 2005 & 2006 & 2007 & 2008 & 2009 & 2010 & 2011 & 2012 & 2013 & I-VI 2014 \\
\hline 0 & 128 & 97 & 0 & 6 & 0 & 61 & 68 & 32 & 0 \\
\hline
\end{tabular}

Źródło: opracowanie własne na podstawie danych z COFM.

Baza obejmuje okres blisko 10 lat - od 2005 r. do połowy 2014 r. W tym czasie skumulowana wartość chińskich BIZ w Polsce wyniosła $392 \mathrm{mln}$ dol., a najwyższe napływy zanotowano w latach 2006-2007, gdy wyniosły 128 i 97 mln USD. W obu przypadkach za całkowitą kwotę odpowiadała jedna transakcja w sektorze maszyn i urządzeń (equipment sector).

\section{Zakończenie}

Przeprowadzona analiza źródeł danych pozwala odrzucić przydatność statystyk o wielkości chińskich BIZ w Polsce publikowanych w przygotowywanym przez MOFCOM, NBS i SAFE „Biuletynie” oraz bazy CGIT prowadzonej przez The Heritage Foundation wraz z The American Enterprise Institute. Pozostałe są cennymi, choć niekompletnymi źródłami informacji na ten temat. Szczególnie godne polecenia są dane publikowane przez OECD, a zbierane przez NBP, dotyczące kraju pochodzenia podmiotów kontrolujących inwestorów bezpośrednich, a do analizy sytuacji bieżącej bazy odpłatne - fDi Markets i Thomson Reuters Datastream, 
udostępniające informacje na temat inwestycji typu greenfield oraz fuzji i przejęć. Przydatne są również statystyki rzetelnie gromadzone przez Rhodium Group. Główne zalety i wady opisywanych w artykule źródeł informacji na temat chińskich BIZ w Polsce zebrano w tab. 10.

Tabela 10. Główne zalety i wady porównywanych źródeł informacji na temat chińskich BIZ w Polsce

\begin{tabular}{|c|c|c|}
\hline & Zalety & Wady \\
\hline 1 & 2 & 3 \\
\hline $\begin{array}{l}\text { MOFCOM } \\
\text { NBS } \\
\text { SAFE }\end{array}$ & $\begin{array}{l}\text { - Dane publicznie dostępne } \\
\text { - Zachowane podstawowe standardy } \\
\text { międzynarodowe pomiaru BIZ } \\
\text { - Tylko transakcje faktycznie zrealizo- } \\
\text { wane }\end{array}$ & $\begin{array}{l}\text { - Metodologia w języku chińskim } \\
\text { - W strukturze geograficznej brak po- } \\
\text { działu BIZ na komponenty } \\
\text { - W strukturze geograficznej domi- } \\
\text { nacja finansowych centrów offshore } \\
\text { z powodu raportowania przepływów } \\
\text { do pierwszej zagranicznej jurysdykcji } \\
\text { - Round-tripping - zaliczanie do BIZ } \\
\text { przepływów, których celem jest zain- } \\
\text { westowanie kapitału w Chinach jako } \\
\text { inwestor zagraniczny } \\
\text { - Pomijanie mniejszych BIZ }\end{array}$ \\
\hline NBP wg IIC & $\begin{array}{l}\text { - Zachowane międzynarodowe standar- } \\
\text { dy pomiaru BIZ } \\
\text { - Wyszczególnione komponenty BIZ } \\
\text { - Drobiazgowo gromadzone dane } \\
\text { - Tylko transakcje faktycznie zrealizo- } \\
\text { wane } \\
\text { - Dane publicznie dostępne }\end{array}$ & $\begin{array}{l}\text { - Klasyfikacja geograficzna BIZ po } \\
\text { kraju rejestracji inwestora bezpośred- } \\
\text { niego } \\
\text { - Dane publikowane raz w roku, ponad } \\
11 \text { miesięcy po zakończeniu badanego } \\
\text { okresu }\end{array}$ \\
\hline NBP wg UIC & $\begin{array}{l}\text { - Identyfikacja Chin jako kraju pocho- } \\
\text { dzenia podmiotu kontrolującego in- } \\
\text { westora bezpośredniego } \\
\text { - Zachowane międzynarodowe standar- } \\
\text { dy pomiaru BIZ } \\
\text { - Tylko transakcje faktycznie zrealizo- } \\
\text { wane } \\
\text { - Dane publicznie dostępne }\end{array}$ & $\begin{array}{l}\text { - Brak przepływów z tytułu BIZ, tylko } \\
\text { stany należności na koniec okresu } \\
\text { - Brak danych na stronie internetowej } \\
\text { NBP } \\
\text { - Dane publikowane ponad rok po za- } \\
\text { kończeniu badanego okresu }\end{array}$ \\
\hline CGIT & $\begin{array}{l}\text { - Identyfikacja Chin jako kraju pocho- } \\
\text { dzenia podmiotu kontrolującego in- } \\
\text { westora bezpośredniego } \\
\text { - Baza aktualizowana co pół roku }\end{array}$ & $\begin{array}{l}\text { - Wysoka dolna granica wartości trans- } \\
\text { akcji uwzględnianych w bazie } \\
\text { - Transakcje zapowiadane } \\
\text { - Transakcje odwołane } \\
\text { - Niezachowana definicja BIZ } \\
\text { - Szacowane wielkości BIZ }\end{array}$ \\
\hline Rhodium Group & $\begin{array}{l}\text { - Identyfikacja Chin jako kraju pocho- } \\
\text { dzenia podmiotu kontrolującego in- } \\
\text { westora bezpośredniego } \\
\text { - Publikacja danych tuż po zakończeniu } \\
\text { roku kalendarzowego } \\
\text { - Zgromadzenie BIZ typu greenfield } \\
\text { i M\&A }\end{array}$ & $\begin{array}{l}\text { - Brak publicznie dostępnych danych } \\
\text { rocznych dla poszczególnych odbior- } \\
\text { ców BIZ } \\
\text { - Nie uwzględnia dezinwestycji } \\
\text { - Szacowane wielkości BIZ }\end{array}$ \\
\hline
\end{tabular}




\begin{tabular}{|c|c|c|}
\hline 1 & 2 & 3 \\
\hline fDi Markets & $\begin{array}{l}\text { - Identyfikacja Chin jako kraju pocho- } \\
\text { dzenia podmiotu kontrolującego in- } \\
\text { westora bezpośredniego } \\
\text { - Wskazanie inwestycji typu greenfield, } \\
\text { często pomijanych przez inne źródła } \\
\text { - Dane bieżące }\end{array}$ & $\begin{array}{l}\text { - Tylko inwestycje typu greenfield, ba- } \\
\text { zowanie na zapowiedziach z momen- } \\
\text { tu ogłoszenia } \\
\text { - Szacowane wielkości BIZ } \\
\text { - Kosztowny dostęp do bazy danych }\end{array}$ \\
\hline Bazy M\&A & $\begin{array}{l}\text { - Identyfikacja Chin jako kraju pocho- } \\
\text { dzenia podmiotu kontrolującego in- } \\
\text { westora bezpośredniego } \\
\text { - Dane bieżące }\end{array}$ & $\begin{array}{l}\text { - Tylko fuzje i przejęcia } \\
\text { - Szacowane wielkości BIZ } \\
\text { - Kosztowny dostęp do bazy danych }\end{array}$ \\
\hline
\end{tabular}

Źródło: opracowanie własne.

Wszystkie źródła wiarygodnych danych o bezpośrednich inwestycjach zagranicznych potwierdzają dynamiczny wzrost chińskich BIZ w ostatnich kilkunastu latach. W 2015 r. lub 2016 r. Chiny stały się eksporterem kapitału netto w formie BIZ i awansowały do ścisłego grona największych inwestorów bezpośrednich na świecie. Przedsiębiorstwa „zza muru” coraz więcej środków przeznaczają nie tylko na pozyskanie dostępu do surowców wydobywanych w krajach rozwiniętych, ale również na przejęcia dużych, globalnych firm, utworzonych w bogatych krajach Zachodu - w Stanach Zjednoczonych czy Unii Europejskiej. Większa aktywność Chińczyków na arenie międzynarodowej - w sferze zarówno politycznej, jak i gospodarczej - wywołuje obawy obywateli i rządów wielu państw rozwiniętych, także z powodu braku jasnych i szczegółowych informacji dotyczących tego procesu. Jest to szczególnie widoczne od dwóch lat - po skokowym wzroście akwizycji dokonanych w USA i UE w 2016 r., w tym przejęciu niemieckiego lidera w branży robotyki - firmy Kuka, czy ogłoszeniu największej w historii chińskiej inwestycji zagranicznej - zakupu szwajcarskiego giganta branży chemicznej, Syngenty, za 43 mld dol. Śledzenie przepływów kapitału pochodzącego z Chin jest jednak utrudnione - z powodu zarówno niedostatków chińskich statystyk, jak i wyjątkowo częstej praktyki wykorzystywania finansowych centrów offshore do ulokowania środków w innym kraju.

Rzetelne określenie poziomu chińskich BIZ w poszczególnych krajach jest pierwszym krokiem w procesie identyfikowania przyczyn czy efektów tego typu inwestycji. W konsekwencji jest również fundamentem pod sformułowanie odpowiedniej polityki państwa wobec inwestorów z Państwa Środka. Zastosowanie danych nieoddających faktycznego stanu rzeczy może doprowadzić do fałszywych wniosków i w konsekwencji poważnych błędów w polityce gospodarczej państwa. Uwzględnienie wymienionych $w$ artykule zastrzeżeń wobec zbiorów danych i rekomendacji ich odpowiedniego wykorzystania pozwoli autorom kolejnych analiz zbudować bardziej dokładny, aktualny i złożony obraz chińskich BIZ w Polsce. 


\section{Literatura}

Blanchard O., Acalin J., 2016, What Does Measured FDI Actually Measure? (no. PB16-17).

Buckley P.J., Sutherland D., Voss H., El-Gohari A., 2013, The economic geography of offshore incorporation in tax havens and offshore financial centres: The case of Chinese MNEs, Journal of Economic Geography, 15(1).

Chiriu A., 2014, The Chinese influence in central Eastern Europe during the global economic crisis, Китаєзнавчі дослідження 1-2.

Éltetö A., Szunomár A., 2016, Chinese investment and trade - strengthening ties with Central and Eastern Europe, International Journal of Business and Management, vol. IV(1).

Haberly D., Wójcik D., 2014, Tax havens and the production of offshore FDI: an empirical analysis, Journal of Economic Geography, 15(1).

Hanemann T., Huotari M., 2015, Chinese FDI in Europe and Germany. Preparing for a New Era of Chinese Capital, Mercator Institute for China Studies i Rhodium Group.

Heiduk G., McCaleb A., 2014, Chinese FDI and Financial Engagement in Poland, [w:] Szunomár A. (red.), Chinese Financial Assistance in Visegrad Countries: Myth or Reality?, Institute of World Economics Centre for Economic and Regional Studies of the HAS.

MOFCOM, NBS, SAFE, Statistical Bulletin of China's Outward Foreign Direct Investment, wydania $\mathrm{z}$ lat 2012-2016.

NBP, 2018, Zagraniczne inwestycje bezpośrednie w Polsce w 2016 r.

OECD, 2008, OECD Benchmark Definition of Foreign Direct Investment, edycja 4.

PAIiIZ, 2004, Lista największych inwestorów zagranicznych w Polsce.

Szunomár A., Biedermann Z., 2014, Chinese outward FDI in Europe and the Central and Eastern European Region within a Global Context, Institute of World Economics Centre for Economic and Regional Studies HAS Working paper, 207.

Zorome A., 2007, Concept of offshore financial centers: In search of an operational definition, IMF Working Papers 07/87.

\section{Źródła internetowe}

Bankier.pl, https://www.bankier.pl/gielda/notowania/akcje/BIOTON/akcjonariat (20.03.2018).

Baza danych Eurostatu http://ec.europa.eu/eurostat/web/balance-of-payments/data/database (20.03.2018).

Baza danych fDi Markets, https://www.fdimarkets.com/ (20.03.2018).

Baza danych OECD, https://stats.oecd.org (20.03.2018).

Baza danych The China Global Investment Tracker, http://www.aei.org/china-global-investmenttracker/ (20.03.2018).

Baza danych UNCTAD Bilateral FDI Statistics, http:/unctad.org/en/Pages/DIAE/FDI\%20Statistics/ FDI-Statistics-Bilateral.aspx (20.03.2018).

Brown D., Chan C., 2018, PwC M\&A 2017 Review and 2018 Outlook, PwChttps://www.pwcen.com/ en/deals/publications/ma-2017-review-and-2018-outlook.pdf (20.03.2018).

FAO, Methodology and scope of the data, http://www.fao.org/economic/est/issues/investment/trends/ methodology-data/en/\#.WrIZAWrOWpq (20.03.2018).

Goh B., Glenn E., McClellan P., 2017, China to curb "irrational” overseas Belt and Road investment: state planner, Reutershttps://www.reuters.com/article/us-china-economy-odi/china-to-curb-irrational-overseas-belt-and-road-investment-state-planner-idUSKCN1AY0FN (20.03.2018).

Kalwasiński M., 2017, Chińczycy rezygnuja z kupna Konsalnetu, https://www.bankier.pl/wiadomosc/ Chinczycy-rezygnuja-z-kupna-Konsalnetu-7530495.html (20.03.2018). 
Kalwasiński M., 2018, Chińskie inwestycje w Polsce: cisza przed burza, Bankier.pl, https://www. bankier.pl/wiadomosc/Chinskie-inwestycje-w-Polsce-cisza-przed-burza-7568699.html (20.03.2018).

Kengelbach J., Keienburg G., Schmid T., Sievers S., Gjerstad K., Nielsen J., Walker D., 2017, The 2017 M\&A Report: The Technology Takeover, Boston Consulting Group, https:/www.bcg.com/ publications/2017/corporate-development-finance-technology-digital-2017-m-and-a-reporttechnology-takeover.aspx (20.03.2018).

Kynge J., 2018, China's Ye Jianming to relinquish stake and role in CEFC Europe, Financial Timeshttps://www.ft.com/content/6369377c-2b9c-11e8-9b4b-bc4b9f08f381 (20.03.2018).

PAIH, 2018, Polska liderem Unii Europejskiej w inwestycjach zagranicznych, https://www.paih.gov. pl/20180201/polska_liderem_UE_w_BIZ (20.03.2018).

Shepherd C., Mason J., Coghill K., 2017, China issues draft guidelines on overseas investment amid crackdown on deals, Reutershttps://www.reuters.com/article/us-china-investment-overseas/ china-issues-draft-guidelines-on-overseas-investment-amid-crackdown-on-deals-idUSKBN1D306Z (20.03.2018).

Thompson B., Feng E., 2018, Chinese M\&A boom provides slim pickings for global law firms, Financial Times, https://www.ft.com/content/2b4901bc-e414-11e7-8b99-0191e45377ec (20.03.2018).

Wu K., Anantharaman M., 2017, China clampdown on overseas deals crimps Asia Pacific M\&A volumes in 2017, Reuters, https://www.reuters.com/article/us-asia-m-a/china-clampdown-on-overseas-deals-crimps-asia-pacific-ma-volumes-in-2017-idUSKBN1EN03G (20.03.2018). 